\title{
RESEARCH PAPER \\ Transportation costs, agricultural expansion and tropical deforestation: Theory and evidence from Peru
}

\author{
Iván M. Lucich ${ }^{1}$, Mauricio G. Villena ${ }^{2}$, and María José Quinteros ${ }^{2}$ \\ 'Departamento de Economía. Pontificia Universidad Católica del Perú. Ave. Universitaria 1801, San Miguel, \\ Lima 32, Peru. \\ ${ }^{2}$ Escuela de Negocios, Universidad Adolfo Ibáñez. Avenida Diagonal las Torres 2640, Peñalolén. Santiago, \\ Chile.
}

\begin{abstract}
I.M. Lucich, M.G. Villena, and M.J. Quinteros. 2015. Transportation costs, agricultural expansion and tropical deforestation: Theory and evidence from Peru. Cien. Inv. Agr. 42(2):153-169. The growth of urban areas adjacent to forest areas, as well as international trade growth, has accelerated the demand for food. These areas of growth have led to the deforestation of tropical forests, a process that contributes negatively to climate change, and a decline in the provision of environmental services and biodiversity. This article seeks to propose and simulate a theoretical model of optimal control at the household level. This model is used to explain the dynamics of forest loss by expansion of the agricultural frontier. Under these conditions, based on tradable permanent crops, farmers decide whether to install new areas for cultivation or manage existing ones in a context of increasing transportation costs. We simulate a theoretical model using data on permanent crops in the high forest of Peru. The results of the model establish that there is a limit to the expansion of the agricultural frontier of the rainforest due to transportation costs. This limit can be surpassed in the context of the free movement of labor whenever these costs cause a decrease and/or increase in the price of land cultivation. Finally, the main policy recommendations of this study emphasize the subordination of transport policy to agroforestry and the conservation of forest ecosystems policies. Agroforestry design forest policies should consider the differential impact of the construction of highways and rural roads on the loss of tree cover as well as on sustainable food production, given that deforestation is not accelerated by the mere existence of roads but by the incentives that are presented to settlers to guide their efforts toward clearing new forest areas.
\end{abstract}

Key words: Agriculture, deforestation, transportation costs, Peruvian Amazon.

\section{Introduction}

The growing concern over the decrease of the tropical forest is associated with the potential economic consequences of climate change and

Received October 10, 2014. Accepted June 18, 2015. Corresponding author: mauricio.villena@uai.cl the loss of biological diversity and environmental services. According to the Intergovernmental Panel on Climate Change (IPCC), deforestation accounts for 13\% of GHG emissions (IPCC, 2014). These problems only acquired relevance in the economic literature in the 1990s (Barbier, 2001; Barbier and Burges, 1997). During that decade, the annual reduction of the natural tropical forest was $1 \%$ (15.2 
million ha), $70 \%$ of which was used for agriculture, primarily permanent crops (PNUMA, 2002). Recent studies confirm that the direct conversion of forest to large-scale agriculture is the main cause of deforestation (Barbier, 2004).

The growth of urban areas adjacent to forest areas and the growth of international trade have accelerated the local and global demand for cropland from the rainforest, as is demonstrated in DeFries et al. (2010). As a result of the growing demand for food, large-scale mechanized agriculture in the tropical forest has been accelerated as an alternative to traditional and subsistence agriculture (Morton et al. 2006). Large-scale mechanized agriculture has encouraged both the expansion and intensification of land use on the border of the rainforest. In Mato Grosso, large-scale mechanized agriculture was the cause of $38 \%$ of deforestation between 2001 and 2004. However, this new form of agriculture in the tropical forest is more pronounced in Brazil than it is in Peru, mainly because of the geographical conditions of the latter (with its extensive zone of "high forest" or "jungle"). These difficult geographical conditions have also limited the development of infrastructure for access to the forest and the expansion of the agricultural frontier (Escobal and Torero, 2000). In Peru, the expansion of tradable permanent crops has been triggered by the emergence of population centers and by political and economic pressure from settlers to improve their roads. The densification and agricultural intensification of these population centers have contributed to the slowing of the process of agricultural expansion on the tropical forest (Piu and Menton M, 2013).

The model of expansion of the agricultural frontier that is presented in this article characterizes the behavior of settler families in the jungle and high forest of Peru. These families are producers of tradable crops with high commercial demand such as coffee, oil palm and cocoa; usually combining long maturation crops with short maturation crops, such as rice, corn, cassava and coca to generate liquidity for their day-to-day expenses.
Regions with "abundant forest" and free access conditions (e.g., Sub-Saharan Africa, eastern and southern Asia, the South American tropical forest) are susceptible to deforestation given the expansion of the agricultural frontier (López, 1996). Extensive agricultural practices that use low levels of fertilization and irrigation contribute to this deforestation. Despite technological improvements in the intensive use of soil, intensive agriculture represents only $10 \%$ of the deforested area (Barbier, 2004).

The disparities that have been observed in the expansion of the agricultural frontier in different regions are due not only to the type of agriculture that is used but also to the distance and integration between rural areas and markets (López, 1996). Thus, for example, the differences in the deforestation rates of Central (1.3\%) and South America $(0.5 \%)$ are due to the fact that a large portion of the natural forest in the latter is located in remote areas, which requires public infrastructure for its exploitation (López, 1996). The expansion of the agricultural area with tradable crops (such as coffee and cocoa) has typically depended on access to the forest and distance to the market (Chomitz and Gray, 1996; Angelsen, 1999 and Angelsen et al., 1999). Moreover, this expansion has responded to the growth of populated areas and to political and economic pressure from settlers for improved roads (Reis and Weinhold, 2004; Deng et al., 2011). The densification and agricultural intensification of these populated areas has, in turn, contributed to the deceleration of the agricultural expansion processes over the forest.

The economic literature has shown that improvements in the transport infrastructure encourage the expansion of the agricultural frontier over the non-intervened tropical forest (Chomitz and Gray, 1996; Angelsen, 1999; Angelsen et al., 1999). Other work is presented by Nelson et al. (2001), which explains the probability of occurrence of a change in land use in a given location in terms of changes in the geophysical and socioeconomic characteristics of different 
areas or localities. In these studies, transportation costs have been measured as the distance from a specific destination using the methodology of Chomitz and Gray (1996).

The theoretical model that is proposed in this study characterizes this result using a dynamic system that analyzes the incidence of transportation costs over different agricultural activities that are carried out by a household to maximize its discounted benefit flows. The model then determines if the household will decide to install new crop areas or manage already existing ones. In particular, our theoretical formulation contributes to the literature in several respects. First, we adopt a characterization of transportation costs in which the amount of work that is required to transport supplies and products is a function of the accessibility of the forest frontier in terms of the distance from an occupied area and the availability and quality of the transport infrastructure. Unlike previous studies, our model distinguishes between the costs of transporting produce and those of transporting human labor. Second, we also consider agricultural tasks as a variable and determine the optimal quantity of this variable as a direct function of the transportation costs. Finally, contrary to previous theoretical approaches, in our model, agricultural tasks refer to "plantation management," primarily weeding and fertilization activities. This alternative formulation allows us to obtain that a decrease in transportation costs affects the trade-off that exists between weeding and pruning activities and the continuing advance over the non-intervened forest (based on a crop mix that associates coffee, cocoa, and coca leaf crops) as the main result of our theoretical model. This finding factors in that the households face growing transportation costs in terms of reaching their property and transporting their produce and that they must follow an optimal program of expansion and incorporation of organic material that would allow them to sustain their plantations. Although these production systems are currently associated with short-cycle crops (e.g., rice, coca leaf), slash-and-burn agriculture is not a predomi- nant practice for coffee or coca crops and is used only when the permanent crops disintegrate and there is a shift towards migratory agriculture.

We also use comparative statistics to analyze the incidence of both transportation cost and crop price over the change in the inventory-stock of a forest in equilibrium and over the quantity of daily wages that are required to manage the plantations.

Finally, we simulate equilibrium dynamics to characterize the determinants of the expansion of the agricultural frontier in the Apurímac - Ene River Valley (AERV). We use empirical data on permanent crops in the high forest of Peru. This analysis focuses mainly on analyzing the sensitivity of the limit of such expansion, given the changes in transportation conditions. To accomplish this task, we characterize and parameterize the functional forms of our theoretical model using information from the agricultural production systems of the Sivia, Pichari-Quimbiri, and Santa Rosa districts. The data comes from the household survey carried out by Wachholtz (1996) for the year 1995 and from the Peruvian Natural Resources Institute (Instituto Nacional de Recursos Naturales, INRENA, 2000) regarding deforestation patterns for 1995. In addition, we also use data on land use change for the area of study for the period 1995-2004, which was obtained from satellite images that were provided by the Monitoring Program of the United Nations Office on Drugs and Crime for Peru (Programa de Monitoreo de Cultivos Ilícitos de la Oficina de Naciones Unidas contra la Droga y el Delito).

\section{Materials and methods}

\section{The model}

The model describes the dynamic optimization process of the utility of a frontier colonizing household, which is representative of an association of tradable permanent crop producers whose cooperative behavior allows for an understand- 
ing of their problem as one that is faced by an association that acts in a centralized manner. The international market determines the price of these products. The household maximizes the present value of its utility $U($.), which is defined as consumption $C_{(t)}$ and time dedicated to leisure $l_{(t)}$ (eq. 1) and which is subject to changes in the forest inventory (eq. 2) as well as budgetary (eq. 3) and time restrictions (eq. 4), which begins with a decision regarding the amount of human labor to be hired $L_{(t)}^{h}$, the size of the expansion of the crop area over the tropical forest $D_{(t)}$, and the amount of daily wages to be used for crop management labor $E_{(t)}$ over the entire farmed area $H_{(t)}=A-F_{(t)}$; with $\mathrm{A}$ being the total area and $F_{(t)}$ the available forest area in a given $\mathrm{t}$ time period; that is:

$\underset{L^{n}, D, E}{\operatorname{Max}} \int_{0}^{\infty} U\left(C_{(t)}, l_{(t)}\right) e^{-\delta t} d t$

Subject to:

$d F_{(t)} d t=-D_{(t)}$

$S_{(t)}+C_{(t)}=P * f\left(A-F_{(t)}, E_{(t)}\right)-w * L_{(t)}^{h}-r X_{(t)}$

$L+L_{(t)}^{h}=l_{(t)}+L_{(t)}^{d}$

The function $U(\cdot)$ is concave and additively separable, $U_{i}>0, U_{i}<0, U_{j}=0$; with $\delta$ being the inter-temporal discount rate.

Based on equation (3) and without loss of generality, the model assumes no savings $S_{(t)}=0$ and that the only existing supply is the work force, which renders the other supplies null $X_{(t)}=0$. In this way, it is established that all of the income is consumed. The cost of household consumption $C_{(t)}$, which is normalized to the unit price, equals the income from the sale of the agricultural product $f\left(A-F_{(t)}, E_{(t)}\right)$, which is valued at price $P$. Meanwhile, the net costs of hiring a work force $L^{h}$ at wage $w$ depend on the mobility of the work force. Production is a function of the agricultural tasks of plantation management $E_{(t)}$ and of the farmed area $H_{(t)}$, which is expressed as the difference between the size of area $A$ and the forest inventory $F_{(t)}$ at year $t$; that is $H_{(t)}=A$ $F_{(t)}$. A portion of such area corresponds to each household (The model considers that all nonwasteland deforested areas are cultivated). The production function is monotonically increasing and strictly concave in "land" $H_{(t)}$ and "work" $E_{(t)}$; that is: $f_{i}>0 ; \quad f_{i}<0 ; \quad f_{j}>0 ; \quad i, j=1,2$, being $f_{H}=-f_{F}$.

Equation (4) shows the equilibrium of the work force. In this equation, the annual availability of time $L$ - which is fixed - and the daily wages that can be bought on the labor market $L^{h}$ equal the annual time that is allotted to leisure $l_{(t)}$ and agricultural activities $L_{(t)}^{d}$. These latter terms, measured in daily wages or workdays, are disaggregated in the following equation:

$L_{(t)}^{d}=\underbrace{I\left(D_{(t)}\right)+E_{(t)}}_{\text {Production }}+\underbrace{\tau\left(A-F_{(t)}, E_{(t)}, I\left(D_{(t)}\right) ; q\right)+G\left(A-F_{(t)} ; q\right)}_{\text {Transport }}$

Equations 4 and 5 of the theoretical model refer to the availability and use of the work force and are associated with the data that was presented by Wachholtz (1996) for a typical household in the AERV, as shown in Tables 1 and 2. Wachholtz's (1996) study presents data on work force availability and requirements in the AERV. These data are used as proxy variables to simulate the theoretical study that is proposed in this article.

The first two terms of equation 5 describe the time that is dedicated to agricultural activities in a productive period. The amount of daily wages for the "clearing and planting of a permanent crop" $I\left(D_{(t)}\right)$ is an "efficient technical relation," which is growing and strictly convex, of the deforested area $D(t)$; that is: $I_{D}>0 ; \quad I_{D} \geq 0$. The amount of daily-wages that are used in planting management $E_{(t)}$ is a variable and includes all of those agricultural tasks that exist between the planting and its harvest and between each harvest from a single planting. The most important of these tasks are weeding or weed control, fertilization, and pruning. The distinction between these two activities is relevant because they can be substituted in the model. 
Table 1. Parameterization of the model.

\begin{tabular}{|c|c|c|c|}
\hline Characterization & Requirements & Methodology & Value \\
\hline \multirow[t]{3}{*}{$\begin{array}{l}\text { Area-scale } \\
\text { (in hectares) }\end{array}$} & $\begin{array}{l}\text { Extension of the property } \\
\text { and the crop area / }\end{array}$ & Direct observation (Wachholtz,1996) & $A=185,000$ \\
\hline & household & $\begin{array}{l}\mathrm{F}(0) \text {, the total property area was estimated and the } \\
\text { cultivable area in } 1995 \text { was subtracted. }\end{array}$ & $\mathrm{F}(0)=142,000$ \\
\hline & $\begin{array}{l}\text { Change in crop area / } \\
\text { household }\end{array}$ & $\begin{array}{l}D(0) \text {, was approximated starting with an initial value } \\
\text { of } 3,450 \text { (Lucich, 1999) }\end{array}$ & $\mathrm{D}(0)=3,321$ \\
\hline $\begin{array}{l}\text { Utility } \\
0<\mu_{1} \leq 1\end{array}$ & $\begin{array}{l}\text { Assumption: linear utility } \\
\text { function }\end{array}$ & $U(C, I)=\Psi\left(C^{\mu_{1}}+I^{\mu_{2}}\right)$ & $\mu 1=\mu 2=1$ \\
\hline \multirow{3}{*}{$\begin{array}{l}\text { Production function } \\
\text { (in kilos) } \\
\alpha+\beta \leq 1\end{array}$} & $\begin{array}{l}\text { Amount of daily wages } \\
\text { for coffee and cocoa crop }\end{array}$ & $\begin{array}{l}\text { Regression estimate of the coffee and cocoa } \\
\text { production function. F.P coefficients Coffee: } a=0.47 \text {, }\end{array}$ & $\mathrm{a}=0.5$ \\
\hline & management & $\begin{array}{l}\mathrm{b}=0.46, Z=37 . \text { F.P coefficients Cocoa: } \mathrm{a}=0.60, \mathrm{~b} \\
=0.40, \mathrm{Z}=60 . \text { The parameters were adjusted to the }\end{array}$ & $\mathrm{b}=0.5$ \\
\hline & $\begin{array}{l}\text { Coffee and cocoa } \\
\text { production }\end{array}$ & property production scale and to net income & $Z=100$ \\
\hline \multirow[t]{2}{*}{$\mathrm{Z}>0$} & & Direct observation & \\
\hline & Net household income & & $\mathrm{YN}=1,960$ \\
\hline \multirow[t]{4}{*}{$\begin{array}{l}\text { Installation costs (in } \\
\text { daily wages) }\end{array}$} & $\begin{array}{l}\text { Daily wage requirements } \\
\text { for installing } 6.21 \text { ha and } \\
D(0)=3,450 \text { ha }\end{array}$ & $\begin{array}{l}\boldsymbol{k} \text { and } \boldsymbol{G} \text { are estimated by resolving system } \\
I\left(D_{(t)}\right)=\Gamma D_{(t)}^{\kappa} \text { for } 6.21 \text { ha and } \mathrm{D}(0)=3,450 \text { ha. This is } \\
\text { then adjusted to the \% composition of daily wage }\end{array}$ & $\mathrm{k}=1.5$ \\
\hline & & requirements & $G=8$ \\
\hline & $\begin{array}{l}\text { Daily wage } \% \\
\text { requirements for } \mathrm{I}(.), \mathrm{E}, \\
\mathrm{t}(.) \text {, and } \mathrm{G}(.)\end{array}$ & & \\
\hline & & $I\left(D_{(t)}\right)=\Gamma D_{(t)}^{\kappa}$ & \\
\hline $\begin{array}{l}\text { Harvest of one hectare } \\
\text { (in daily wages) }\end{array}$ & $\begin{array}{l}\text { Daily wage requirements } \\
\text { for harvesting one hectare }\end{array}$ & $\begin{array}{l}\text { Direct observation, considering the average for coffee } \\
\text { and cocoa and assuming that the harvest is carried out } \\
\text { over the entire crop area, independently of crop age }\end{array}$ & $c=5$ \\
\hline \multicolumn{4}{|c|}{ 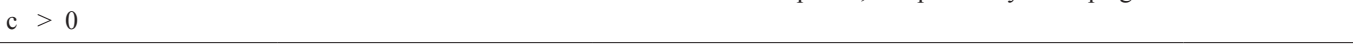 } \\
\hline \multirow[t]{2}{*}{$\begin{array}{l}\text { Work force and produce } \\
\text { transportation costs (in } \\
\text { daily wages) }\end{array}$} & $\begin{array}{l}\% \text { daily wage requirement } \\
\text { for } \mathrm{I}(.), \mathrm{E}, \mathrm{t}(.) \text {, and } \mathrm{G}(.)\end{array}$ & $\begin{array}{l}\text { The value of } q \text { is adjusted to } \mathrm{H}(0) \text { according to the } \\
\text { following conditions: } G() \text { square in } \mathrm{H}, t() \text { linear in } H \text {, } \\
\text { the } \% \text { composition of daily wages, and net income. }\end{array}$ & $\begin{array}{l}q=[0.004 \\
0.0065]\end{array}$ \\
\hline & $\mathrm{E}(0), \mathrm{I}(0), \mathrm{H}(0)$ & $\begin{array}{l}\text { Variable } S \text { adjusts } \Omega \text { to the area destined to } I(.) \text { or } \\
\text { to } E \text {. }\end{array}$ & $W=0.25$ \\
\hline$q>0$ & & & $S=0.01$ \\
\hline \multicolumn{4}{|l|}{$0<W<1$} \\
\hline \multirow[t]{3}{*}{$0<S<1$} & & & \\
\hline & & $\tau()=.q S \Omega\left[A-F_{(t)}\right] \pi\left\{E_{(t)}+\right.$ & $\left.\left.D_{(t)}^{K}\right]\right\}$ \\
\hline & & $G()=.\left\lfloor A-F_{(t)}\right\rfloor q \Omega(A-F) /$ & $+c$ \\
\hline Costs / Prices & Daily wage - Coffee price & Direct observation & $\mathrm{v}=4 \quad-\quad \mathrm{P}=1$ \\
\hline
\end{tabular}

The last two terms in equation 5, which are considered to be "efficient technical relations," describe the time that is used by the workers for their daily transportation between their households and the property and the time that is required for the harvest and transport of the produce to the market, respectively. Although these activities are not linked directly to production, they require time and are necessary for sales. The time that is used by the workers for transportation $\boldsymbol{\tau}\left(A-F_{(t)}, I\left(D_{(t)}\right), E_{(t)} ; q\right)$ depends increasingly on the area that is covered $A-F_{(t)}$ and the number of daily wages that are dedicated to each task, either "clearing and planting" $I\left(D_{t(t)}\right)$ 
Table 2. Deforestation in the study zone: 1995 - 2095.

\begin{tabular}{lccc}
\hline Field (environment) (ha) & Year 1995 & $\begin{array}{c}\text { Year 2095-A } \\
\mathrm{q}=0.004\end{array}$ & $\begin{array}{c}\text { Year 2095-B } \\
\mathrm{q}=0.0065\end{array}$ \\
\hline Total Area & 185,153 & 185,000 & 185,000 \\
Deforestation & 42,846 & 120,410 & 74,099 \\
Forest stock & 142,300 & 64,590 & 110,901 \\
\hline
\end{tabular}

or "plantation management" $E_{(t)}$. However, the time used for harvest and to transport the produce to the market $G\left(A-F_{(t)} ; q\right)$, measured in daily-wages, is a growing and convex function with respect to the deforested area $H_{(t)}=A-F_{(t)}$, or $G_{F}<0 ; \quad G_{F}>0$ (Angelsen et al., 1999). This finding implies that, given the agricultural expansion, the increment in transportation costs occurs at increasing rates because it incorporates not only the new crop area that must be harvested but also the greater distances that need to be covered. The transportation efficiency parameter $q$ captures the quality of the roads and the modes of transport and measures the time that is used in transportation per distance unit covered, which is considered to be a "transport cost."

In this regard, the improvement in transportation conditions, which is to say the reduction of $q$, decreases the costs of transport and marginal transport over the recently deforested area. For policy purposes, the differentiated effect that the change in $q$ generates over the recently deforested area $G_{F q}<0$ and $\tau_{F q}<0$ as well as over the managed agricultural area $\mathrm{G}_{\mathrm{q}}>0$, $\tau_{q}>0, \quad \tau_{E q}>0, \quad \tau_{D q}>0$ should be noted.

\section{Solution of the model}

Replacing equation (5) in (4), and later equations (3) and (4) in the utility function (eq. 1), the utilitymaximizing settler's problem, in a scenario with perfect labor force mobility would determine the size of the forest area to be cleared for crop planting $D(t)$, the amount of daily wages to use $L^{h}(t)$, and how many of these wages to use for plantation management $E(t)$ over the whole farmed area $A-F(t)$. The current value Hamiltonian that allows us to solve this problem is given by (we suppressed time sub-indices, which indicate partial derivatives.):

$$
\begin{aligned}
& \tilde{H}=U\left(P f(A-F, E)-w L^{h}, L+L^{h}-I(D)-\right. \\
& E-\boldsymbol{\tau}(A-F, D, E ; q)-G(A-F ; q))-\lambda D
\end{aligned}
$$

With $D, E$, and $L^{h}$ being the control variables and $F$ the system state variable, the Pontryagin's maximum principle establishes that:

$$
\begin{aligned}
& \frac{\partial \widetilde{H}}{\partial D}=0 ;-U_{2}\left(I_{D}+\tau_{D}\right)=\lambda \\
& \frac{\partial \widetilde{H}}{\partial E}=0 ; U_{1} P f_{2}-U_{2}\left(1+\tau_{E}\right)=0
\end{aligned}
$$

$\frac{\partial \widetilde{H}}{\partial L^{h}}=0 ;-U_{1} w+U_{2}=0$

$\dot{\lambda}-\delta \lambda=-\frac{\partial \widetilde{H}}{\partial F}=0 ; \dot{\lambda}-\delta \lambda=U_{1} P f_{1}+U_{2}\left(\tau_{F}+G_{F}\right)$

$\lim _{t \rightarrow \infty} \lambda_{(t)} F_{(t)}=0$

Equation 7 demands that, to follow the optimal forest exploitation path, the marginal cost of transport towards the frontier (clearing the forest and installing a crop), which is measured in the loss of leisure utility, must equal the marginal cost of the forest inventory for society, represented by $\lambda$ (Mueller, 1997).

The implicit negative price captures the costs that are faced by the settler to deforest the native forest as well as the loss of this resource for society. The standing forest is considered to be an obstacle for the settler that only produces a yield at the end of the period with the production of the installed plantations; the timber is assumed to have no value. To obtain benefits, the deforested 
and harvested area $D_{(t)}$ is incorporated into the production function using the movement equation $d F / d t$ (eq. 10).

The combination of equations (8) and (9) establishes that the optimum amount of effort for management labor occurs when the cost of the marginal product equals the salary.

Equation 10 describes the marginal agricultural benefit that is obtained from the planting of the new crop area and the transportation and sale of the produce to the market. The optimal forest inventory trajectory demands that the change in the implicit price for deforestation (the net of the interest that is not gained due to the crop planting) be equal to the sum of the marginal utilities of consumption and leisure as a consequence of the sale of produce that is generated with additional units of effort in the transport of the labor force and produce.

The transversality condition (eq. 11) indicates that the household will optimally exploit the resource without facing a terminal period (Pascual and Barbier, 2001).

The long-term equilibrium is reached when the rates of change of the state variable and the costate variable are zero; $\dot{F}=\dot{\lambda}=0$. The system that resolves the equilibrium for $F^{*}, D^{*}, E^{*}, L^{h *}$ is given by:

$$
\begin{aligned}
& U_{2}-w U_{1}=0 \\
& P f_{2}-w\left(1+\tau_{E}\right)=0 \\
& \delta w\left(I_{D}+\tau_{D}\right)-P f_{1}-w\left(\tau_{F}+G_{F}\right)=0 \\
& -D=0
\end{aligned}
$$

From equations 13 and 14, we establish that the agricultural expansion over the forest will reach its limit when the agricultural income of such expansion equals the interest that is paid to finance the clearing of an area of the forest and the planting plus the marginal costs of the transportation and harvest of the crops, as well as when the marginal income from managing the plantations equals its marginal costs, including those that are incurred by transporting the workers to the property.

The optimal trajectory for the stock of the forest in equilibrium could be determined qualitatively in a $D-F$ phase diagram, based on the behavior of the isolines $\dot{D}=\dot{F}=0$, starting from the following dynamic system that resolves the problem of the settler:

$$
\begin{aligned}
& \frac{d F}{d t}=-D \\
& \frac{d D}{d t}=\frac{\delta w\left(I_{D}+\tau_{D}\right)-P f_{1}-w\left(\tau_{F}+G_{F}\right)+\Sigma D}{w I_{D D}}
\end{aligned}
$$

Where:

$\Sigma=\left\{-w U_{2} \tau_{E F}\left(I_{D}+\tau_{D}\right)-U_{2} \tau_{D F}\left(P f_{2}-w-w \tau_{E}\right)+\right.$ $\left.\left(w U_{1} P f_{22}\left(I_{D}+\tau_{D}\right)\right) *\left(P f_{21}+w \tau_{E F} / P f_{22}\right)\right\}$

The existence of equilibrium and its "local" nature are proven when a constant slope of the isolines equal to zero is obtained. Given a negative determinant of the Jacobian matrix, there is an optimal path (Figure 1) that would lead us to a stationary equilibrium, which is classified as unstable or a "saddle point" (Hanley et al., 1997). The conditions that are necessary to characterize the equilibrium are summarized in the following result:

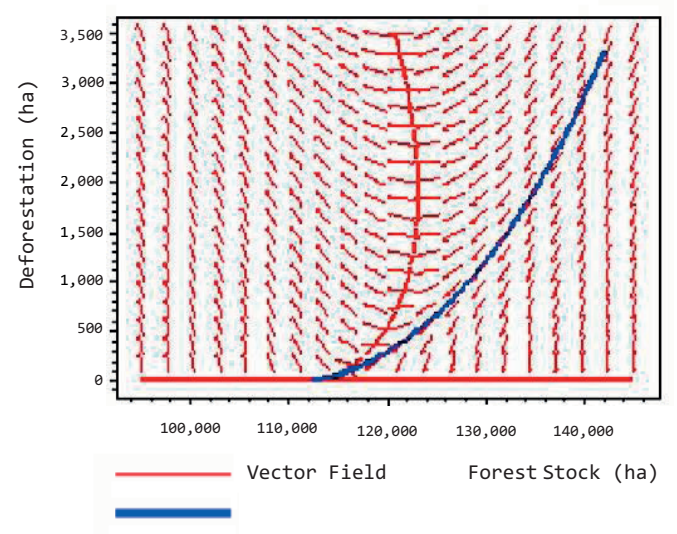

Figure 1. Phase diagram and optimal path. 
Result 1: The necessary condition for the existence of a limit to the expansion of the plantations with commercial value over the tropical forest, which is a "local" equilibrium with a "saddle point" characteristic, is that the production function of a representative settler be concave with respect to the deforested surface and that the transportation costs be convex with respect to the same variable.

This result implies that there is an optimal path that would allow a settler to maximize utility without preying on the forest resource as long as the optimal conditions are met.

\section{Comparative statistics}

The long-term equilibrium decisions that are taken by the household regarding the size of the agricultural area and the amount of daily wages to be used in crop management will be altered by changes in transportation conditions and the price of the crop. We evaluate the incidence of these factors over the inventory of the forest in equilibrium and the amount of daily wages that are assigned to crop management using Cramer's rule.

The effect of an improvement in transportation conditions. Improved transportation conditions reduce "the time that is used for transportation per unit of distance" $q$, which decreases the marginal cost of transportation for all activities, whether moving the labor force $\left(\tau_{D}, \tau_{E}, \tau_{F}\right)$ or taking produce to the market $G_{F}$. The direct effect of this improvement is an increase in the need for daily-wages for both deforestation and crop planting tasks $\left(d F^{*}\right)$ and for crop management $\left(d E^{*}\right)$, as shown by the conditions of optimality (eq. 8 and 10).

The magnitude of the expansion of the agricultural area (eq. 18) depends on how much the agricultural production decreases if "crop management" increases $\left(f_{22}\right)$ and on how much production increases if these two agricultural activities complement each other $\left(f_{21}\right)$ : the net costs of transport over the new area $\left(P f_{21}+w \tau_{F E}\right)$.

$\frac{d F^{*}}{d q}=\frac{\left\{P f_{22} w\left(G_{F q}+\tau_{F q}-\delta \tau_{D q}\right)+w \tau_{E q}\left(P f_{21}+w \tau_{F E}\right)\right\}}{\Delta}>0$

The greater need for daily wages for "crop management" (eq. 19) has two sources: improved production that is caused by complementing both agricultural activities $\left(P f_{21}+w \tau_{F E}\right)$ and decreased marginal costs of transporting the labor force for management activities $w \boldsymbol{\tau}_{E q}$ , which is a direct consequence of transportation improvement. The magnitude of this last source depends on the decreasing yield of the land (which is due to the reduction of the forest) and on the increasing marginal costs that are associated with agricultural expansion activities, i.e., clearing and crop planting in the new area and transporting produce to the market: $P f_{11}+w\left(\delta \tau_{D F}-\tau_{F F}-G_{F F}\right)$.

$\frac{d E^{*}}{d q}=\frac{\left\{\left(P f_{21}+w \tau_{E F}\right)\left(G_{F q}+\tau_{F q}-\delta \tau_{D q}\right) w+w \tau_{E q}\right.}{\Delta}$

$\frac{\left.\left(P f_{11}+w\left(\delta \tau_{D F}-\tau_{F F}-G_{F F}\right)\right)\right\}}{<0}<0$

As a consequence of the greater work requirement for both deforestation and crop planting activities and for "crop management," we expect a greater use of daily-wages, given that increasing production also increments consumption and leisure. This would be possible in the measure that the household reduces its own work efforts and hires more workers.

The effect of an increase in crop price. Higher crop prices encourage the demand for "production factors" $d F^{*}, d E^{*}$ as a result of increasing the value of the marginal products over the marginal costs (eq. 8 and 10).

The magnitude of the expansion of the agricultural frontier (eq. 20) depends on the decreasing marginal yields of "crop management" tasks $\left(f_{22}\right)$, from which lower incomes would be obtained, and from the incomes that are generated by "plantation management" over the new area: the net costs of transporting the work force over 
said area $\left(P f_{21}+w \tau_{F E}\right)$.

$$
\frac{d F^{*}}{d P}=\frac{\left\{P f_{22} f_{1}-\left(P f_{21}+w \tau_{F E}\right) f_{2}\right\}}{\Delta}<0
$$

The greater requirement of daily wages for "plantation management" (eq. 21) results from the decreasing marginal yields of the expansion of the agricultural area $\left(f_{11}\right)$, which, unlike the effect of price over agricultural expansion $\left(d F^{*}\right.$ / $d P)$, is accentuated by the growing marginal costs of deforestation and crop planting.

$\frac{d E^{*}}{d P}=\frac{\left\{\left(P f_{21}+w \tau_{E F}\right) f_{1}-\left(P f_{11}-w\left(\tau_{F F}+G_{F F}-\delta \tau_{D F}\right)\right) f_{2}\right\}}{\Delta}>0$

The effects that are generated over the agricultural surface and over the use of daily wages for "crop management" are summarized in the following result:

Result 2: Considering perfect mobility of the work force, concave production, and convex transportation costs, both the improvement in transportation conditions and the increase in crop prices encourage the expansion of the plantations with commercial value over the tropical forest; the need for daily wages for "plantation management" in the deforested area also increases. This increase elevates the utility of the households, increasing consumption and leisure time.

An analysis of equations 18, 19, 20, and 21 shows that the consideration of transportation costs for the work force amplifies the magnitude of the effects that are generated by transportation and prices policies over the changes in the agricultural area and the amount of daily wages for "plantation management."

On the other hand, given a greater demand for consumption and leisure, a household can reduce its own work hours by hiring more workers. The decision as to the amount of leisure time that a household wishes to maintain is independent of the amount of daily wages that are demanded by agricultural activities, thus proving the property of separability.
The restriction of labor supply and intensification of transport infrastructure

The previous model assumes no restrictions in work force mobility and that the migratory process is motivated by the increasing demand for labor by the frontier-colonizing household. However, by extending the previous model, it can be shown that, given a context of restricted labor supply and risk neutrality, for an improvement in transport infrastructure not to encourage the expansion of the agricultural frontier, the opportunity cost to expand new farming areas (given by the value that is generated based on leisure or plantation management) must exceed the income that is generated by installing new crops, if and only if such improvement occurs over cultivated areas and not over non-intervened forest. In this context, improvements in transport conditions do influence the existing trade-off between plantation management and the advancement over the non-intervened forest. Deng et al. (2011), Reis and Weinhold (2004) and Chomitz and Gray (1996) empirically corroborated this theoretical result with respect to the effect of intensifying paths over colonized areas, as did Angelsen (1999) with respect to the restriction of the labor supply. Otherwise, any improvement should always encourage the expansion of the agricultural frontier (Weinhold and Reis, 2008, Morton et al., 2006).

It should be noted that the results of our model are not affected by alternative, more complex, dynamic relations when considering non-linear responses to the parameters, either of the agricultural systems production function or the forest stock function.

\section{Socioeconomic characteristics}

The characteristics of the agricultural production systems in the AERV. The Apurímac - Ene River Valley is the natural border of the Apurímac, Ayacucho, Cuzco, and Junín Departments. This territory corresponds to a high rainforest 
area where colonization began in the 1960s based on the exploitation of coffee, cocoa, and barbasco. The study by Wachholtz (1996) covers the Sivia and Santa Rosa districts in the Ayacucho department and Pichari-Quimbiri in the Cuzco department. The main crops in the high forest are coffee and cocoa (42\%), corn $(19 \%)$, rice $(11 \%)$, banana $(10 \%)$, coca $(8 \%)$, and others (11\%) (Piu and Menton, 2013). The proportion of the high forest in Peru with permanent crops is $52 \%$ of the total cultivated area (Piu and Menton, 2013).

In 1995, the rural population of the study area reached 26,686 people. These were distributed among approximately 6,900 households, each with an average area of 12 ha. The cultivated area represented $52 \%$ of the property (Wachholtz, 1996).

\section{Results}

The characterization and parameterization of the functional forms

According to the Peruvian Natural Resources Institute, in 1995, the deforested area in the Ayacucho department represented 23\% of the initial forest stock. Thus, we estimate a wooded area of 142,300 ha in the study zone for 1995 (see Table 3a).

Table $3 \mathrm{~b}$ shows the composition of the typical agricultural crop mix in long-cycle agricultural production systems such as cocoa, in which $73 \%$ of the area is occupied by permanent crops. Table $3 \mathrm{~b}$ also gives the work force requirements expressed in daily wages for a typical property of 6.21 ha.

Table 3. Apurímac - Ene Rivers Valley (AERV) information. (3a). Total area and deforestation for 1995 (ha).

\begin{tabular}{lc}
\hline Field (environment) & Study zone \\
\hline Total Area & 185,153 \\
Deforestation & 42,846 \\
Forest stock & 142,300 \\
\hline
\end{tabular}

Source: Adapted from Instituto Nacional de Recursos Naturales (INRENA) (2000).

(3b). Production system of a typical household in the AERV. Source: Wachholtz (1996).

\begin{tabular}{|c|c|c|c|}
\hline \multirow[b]{2}{*}{ Crops } & \multirow{2}{*}{$\begin{array}{l}\text { Cultivated area } \\
\text { cocoa system }\end{array}$} & \multicolumn{2}{|c|}{ Work force/ha requirements } \\
\hline & & Family (daily wage) & Worker (daily wage) \\
\hline Coffee & $8 \%$ & 54 & 26 \\
\hline Cocoa & $65 \%$ & 31 & 28 \\
\hline Coca & $12 \%$ & 88 & 125 \\
\hline Banana & $5 \%$ & 33 & 24 \\
\hline Yuca & $4 \%$ & 38 & 25 \\
\hline Corn & $4 \%$ & 26 & 19 \\
\hline Rice & $2 \%$ & 29 & 19 \\
\hline Total & 6.21 & & \\
\hline
\end{tabular}

Source: Wachholtz (1996). 


\section{The calibration of the model}

In Table 1, we propose specific functional forms that are consistent with the theoretical model for each one of the main equations of the model (eq. 12-15) and the associated parameters based on empirical evidence. In this table, we also summarize the estimation methodology for each parameter, respectively.

The scale parameters depend on the extension of the study area, number of households, extension of the property, and extension of the crop area. Based on these parameters, we can define the size of total area $A$ and of the initial forest stock $F(0)$. The initial value for the decrease in forest stock $D(0)$ is calibrated using the value of $F(0)$ such that it belongs to the optimal path towards equilibrium. A value of 3,450 ha was used to begin the calibration of $D(0)$; this value corresponds to an increase of 0.5 ha per household according to a property monitoring that was carried out in 1999 by Lucich (1999).

Given these parameters, it is valid to consider $A-F$ as a good approximation of $H$, as presented in the theoretical model. Assuming a fixed extension of the total area $A$, we suppose that the model does not include population growth. This growth explains the increase of $A$.

The values that are assigned to the behavior parameters are consistent with the functional forms and with the characteristics of the agricultural production system of the AERV. This consistency shows a relationship with the following points: i) average household income, ii) production function, and iii) availability and use of work force.

\section{Simulation of the model}

In this section, we present the simulation of the theoretical model to explain the dynamics that followed the deforestation in the Valley of the Apurimac River, using information that was collected in some villages in this valley that characterizes the existing agricultural production systems.

Starting with the parameterization of the theoretical model (eq. 12-15) and using Maple mathematical software, we tested the characterization of the equilibrium and determined its long-term values for the forest stock $F^{*}$ and for the amount of daily wages dedicated to crop management $E^{*}$. We also simulated the trajectory that lead to these values, thus resolving the dynamic equations system that explains the changes in forest stock (equation 16) and the deforestation rate (equation 17). For this, we considered the initial values of $F(0)=142,000$ and $D(0)=3,321$ ha. Note that the value of the variable $\mathrm{D}(0)$ used to calibrate the model was 3,450 ha and, after calibration, this value became in 3,321 ha.

As a result, we estimate that the expansion of the agricultural frontier in the AERV, based on permanent crops, leads to an accumulated loss of tree coverage of $40 \%$ to $65 \%$ of the total area over 100 years, with $80 \%$ of this intervention occurring in the first 35 years. This effect is shown in Table 2, in which we consider two transport cost $\boldsymbol{q}$ scenarios.

Table 2 shows that for the long run equilibrium, the total deforested area will increase as long as transportation costs decrease. For instance, if the value of the transportation efficiency parameter is equal to 0.0065 , the loss of forest stock reaches approximately $40 \%$, while if this parameter equals 0.004 , the loss of forest stock would be of $65 \%$ of the total area over 100 years, which is 2095 , taking into account that for the year 1995, the Peruvian Natural Resources Institute registered a loss of $23 \%$ of forest stock for the Ayacucho department.

Consequently, if a decrease of $7 \%$ of transportation costs occur (i.e., the transportation efficiency parameter $q$ diminishes from 0.007 to 0.0065 ) and one of $43 \%$ (i.e., the transportation efficiency parameter $q$ diminishes from 0,007 
Table 4. AERV: Classification of satellite images Landsat TM (ha).

\begin{tabular}{lrr}
\hline Classification & 1994 & 2005 \\
\hline Primary and secondary forest & 532,781 & 522,713 \\
Intervened area & 9,518 & 16,123 \\
Populated area & 7,261 & 14,840 \\
High grounds & 17,022 & 15,657 \\
Clouds & 4,063 & --- \\
Rivers & 18,326 & 19,638 \\
Total (ha) & 588,971 & 588,971 \\
\hline
\end{tabular}

Source: Monitoreo de Cultivos de Coca en el Perú 2005 (UNODC, 2006).

to 0.004$)$, both very feasible scenarios regarding the current land use dynamics, the loss of forest stock would increase from $36 \%$ to $40 \%$, and from $36 \%$ to $65 \%$, respectively. It should be noted that these changes in the results concerning the forest stock, are explained completely by the different transportation costs that are considered in the analysis.

Table 4 shows the results of the classification of satellite images, including the districts of Anco, Vicabamba, San Miguel, Kimbiri, Santa Rosa, Ayna, Sivia, Llochegua, Pichari, Pangoa, Rio Tambo and Chungui.

Located over the optimal path, the expansion of the agricultural frontier, as shown in Figure 2, is much faster at the beginning of each process. The expansion then slows for a long period as it approaches the equilibrium or expansion limit of the agricultural frontier. This can last more than 100 years.

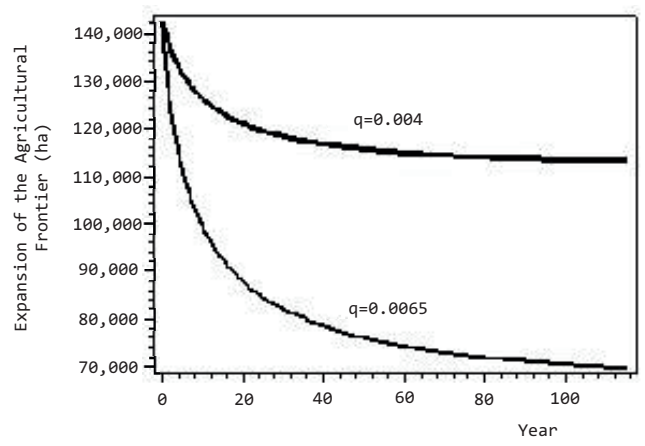

Figure 2. Paths toward equilibrium.
When we take into account the time period of 100 years, we find that a strong characteristic of the process of forest reduction is that, for conventional agricultural production systems, deforestation rates accelerate during the first 10 to 35 years, depending on the reduction level of transportation costs. During this period of time, between $70 \%$ to $80 \%$ of the total forest area that is estimated to be lost would have been deforested. Hence, for instance, considering a value of 0.004 for the transportation efficiency parameter $q$, during the first 20 years, $70 \%$ of the total forest area that is estimated to be lost would be deforested. Under this scenario, we estimate that the loss of forest stock in the context of the area of analysis (Pichari-Quimbiri, Sivia and Santa Rosa) would be of approximately 14,000 ha during a 10 -year period. This represents $10 \%$ of the initial forest stock (Table 2).

Finally, the process of adjustment to the forest stock equilibrium implies a decreasing process of the intensity of the use of the work force for plantation management, given that the demand for daily wages to maintain the expansion of the agricultural frontier decreases due to the concave production function. This process stabilizes at 81 daily wages per ha.

Figure 3 shows the evolution of the forest stock in equilibrium and of the amount of daily wages in equilibrium according to different transportation costs. As predicted by the theoretical model, as transportation costs decrease, the forest stock 
tends to decrease. According to data on land use change for the area of study, which was obtained from satellite images that were provided by the Monitoring Program of the United Nations Office on Drugs and Crime for Peru, the average annual loss of forest stock was $0.18 \%$ for the period 1994-2005, the same rate that applied to the initial forest stock for 1995 produces a loss of forest stock of $36 \%$ of the total area over 100 years. For this analysis it was assumed that the fields were at different stages of the deforestation process dynamics, some following more accelerated rates than others, having on average an annual loss of $0.18 \%$. This estimated level of forest stock loss over a 100 years period $(36 \%)$, which implicitly reveals the current situation of transportation conditions, and therefore, the implicit costs ( $q \cong 0.070$ according to Figure 3), allowed us to assess, simulating the proposed theoretical model, the forest stock loss for this time period as a result of decreases in the transportation costs $(q=0.0065 ; q=0.004)$.

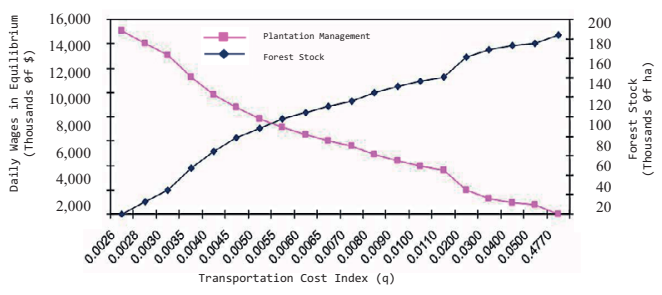

Figure 3. Forest stock - daily-wages in equilibrium, and transportation costs.

In this context, considering a value of 0.0065 for the transportation efficiency parameter $q$, which is a highly likely situation, a $20 \%$ decrease in transportation costs (i.e., for $q$ to go from 0.0065 to 0.0052 ) is expected to cause a decrease of $6 \%$ in the forest stock in equilibrium; that is a loss of 18,000 ha. Of these, 9,000 ha would be deforested within the next ten years. If transportation costs were cut in half, the AERV would lose 35,000 ha of forest ( $18 \%$ of its total area) within 100 years, with the maximum loss occurring during the first 35 years. On the other hand, if the conditions for harvest transportation become more difficult, making q increase by $38 \%$ (i.e., for $q$ to go from 0.0065 to 0.009$), 28 \%$ of plantations would be abandoned and 14,000 ha would become secondary forest.

For the current agricultural expansion process based on permanent crops to stop, transportation costs would need to reach an approximate value of 0.011 , which would represent an increase of almost $100 \%$.

\section{Discussion}

Much of the deforestation in the tropical forest is explained by the migration of small farmers who use the frontier to exploit tradable permanent crops such as coffee and cocoa. These farmers must constantly decide whether to continue to expand their plantations given the resulting increase in transportation costs and the need to follow an optimal program for expansion and organic material incorporation, which allows them to sustain their plantations.

Please consider "The dynamic approach that is used in this article is based on the optimal control theory, which also explains the economic behavior that is adopted by settlers. Settlers are constantly faced with the problem of whether to cause further damage to the rain forest by continuing to manage a single plantation or moving on to a new area". The specification of this model allows us to simulate the dynamics of change in land use to explain the different paths deforestation can take, considering the sequence of decisions that are made by economic agents, which depend on variables of scale and the ratio of relative prices and costs, including transport costs.

Farmers who do not follow the optimal equilibrium path would be expected to abandon their plantations and migrate towards another area or to concentrate their activity on short-cycle crops (e.g., coca leaf). This situation would lead them to a migratory agriculture practice that is based on slashing and burning the forest, which makes 
planting with the intention to sell the harvest in the market progressively more costly. An example of this scenario occurs when deforestation is proposed at growing rates: the loss of tree coverage makes agricultural activity unsustainable because tree coverage is the primary nutrient source of the forest (Bulte and Van Soest 1999, López and Niklischek, 1991, Pascual and Barbier, 2001). Thus, placing us to the right of the forest stock equilibrium level and over the optimal path, the reduction of the forest would accelerate the agricultural expansion rate to maximize a settler's utility, thereby deviating further from the optimal equilibrium path.

The modeling of the dynamics of the forest has many advantages, including analyzing the bidirectionality of the effect of improving roads and reducing vegetation cover. It is true that improving roads reduces coverage, but coverage reduction from improving roads and transportation makes farming more efficient and profitable. Furthermore, dynamic modeling allows us to understand and characterize the sequence of events that occur during the process of loss of vegetation cover as well as the speed of each of those events. The information that is obtained is valuable as it allows us to anticipate the effects of forest loss to implement corrective measures at the right time in the right places.

The simulation of the dynamic model also provides us with qualitative results that allow us to characterize the dynamics of forest stock loss. In this context, this equilibrium is characterized by instability, which means that, in general, any initial combination of daily wages $E(0)$ and farmed areas $A-F(0)$ will cause an imbalance that encourages the abandonment of the plantation. Thus, the model reveals that plantation management is not sustainable unless it follows an optimal management path. In this case, an agricultural frontier that is based on plantations would have reached its maximum expansion limit. The instability that is revealed by the model occurs because the election of $E$ only considers economic and not ecological or environmental objectives. However, the model reveals the existence of an optimal policy that combines $E^{*}$ and $A-F^{*}$ that would sustain agricultural activity and not force its abandonment.

There is evidence that agricultural intervention in the tropical soil is not sustainable unless there is soil erosion control and tree biomass is incorporated. Bulte and Van Soest (1999), López and Niklischek (1991), Pascual and Barbier (2001) agree on this.

The proposed model does not include variables or environmental objectives that refer to soil erosion control or incorporation of tree biomass to support the plantations, but rather work weeding and fertilization. Although these variables do not allow for the accumulation of natural capital, they are technologically available to average farmers and enable them to partially restore nutrients to stay on the growth path, as proposed in Ehui and Hertel (1989), and Angelsen et al. (1999), so it does not have a significant implication for the purposes of the article.

Recent works (Angelsen, 2010; Weinhold and Reis, 2008; Deng et al., 2011) present empirical evidence regarding the improvement of transport infrastructure in areas with settled populations, which slows down the rate of deforestation to a detrimental level. The main arguments that explain the slowdowns are linked to the endogenous development of transport routes from densification of networks, which raises the value of land and intensifies agricultural practices and reduces pressure on adjacent forest areas, mainly through the agro-forestry (Klemick, 2011), the implementation of protected areas, and policies to reduce income from land use.

Another approach to dynamically address the loss of plant cover is the technique of spatial econometrics, for which the data are collected mainly through aerial photographs or satellite images. The analysis by Nelson et al. (2001) 
helps to explain the likelihood of change in land use in a given location as well as changes in the geophysical and socioeconomic characteristics of different areas or localities. This analysis allows us to estimate the marginal effects of exogenous variables on the probability of change in land use and also to simulate the dynamics of forest use.

Although the theoretical model that is proposed in this article presents the basic economic conditions for the expansion process of the agricultural frontier over the tropical forest, we propose the following extensions to gain better control over certain key variables, which would allow for the encouragement of management to follow an optimal path. We propose, for example, the incorporation of the rotation of crops (including short-cycle crops) and a dynamic of secondary forest recovery, which would create an endogenous variable for the model: the transport infrastructure based on the generation process of populated centers and the control of different areas. The latter would allow for a spatial distinction of the effects of improved transportation conditions (through roads, bridges, dirt roads, fees, storage centers, and social organization) over the plantation area and the non-intervened area; this would allow for better regulation of deforestation. To this end, we propose the creation and implementation of new models using primary information.

Finally, among the main policy recommendations that can be inferred from this article, we highlight the following recommendations: (i) coordinate transportation policy (at the regional and national levels) with agroforestry policy initiatives and the conservation of rainforest ecosystems; (ii) consider the differentiated impacts that are associated with the implementation of agroforestry systems and other systems on the land use changes in the amazon rainforest in agricultural policy; and (iii) design policies for the Amazon that consider the differentiated impacts of the construction of highways and rural roads over the loss of forest stock and over the production of sustainable food.

In general, this article emphasizes the need to find control the variables that allow us to discern the loss of the tropical forest and orient the exploitation of long-cycle permanent crops along the optimal forest management path, as deforestation is accelerated not only by the existence of highways but also by incentives that are presented to settlers to reorient agricultural labors towards the clearing of new forest areas.

\section{Resumen}

I.M. Lucich, M.G. Villena y M.J. Quinteros. 2015. Los costos de transporte, la expansión agrícola y la deforestación tropical: Teoría y evidencia de Perú. Cien. Inv. Agr. 42(2): 153-169. El crecimiento de las áreas urbanas adyacentes a las zonas forestales, además del crecimiento del comercio internacional, ha acelerado la demanda de alimentos y por lo tanto la deforestación de los bosques tropicales, un proceso que contribuye negativamente al cambio climático, a la disminución de la provisión de los servicios ambientales y a la biodiversidad. Este artículo tiene como objetivo proponer y simular un modelo teórico de control óptimo a nivel de hogares para explicar la dinámica de la pérdida de bosques por la expansión de la frontera agrícola que hace que un agricultor, en base a cultivos permanentes transables, quien decide en cada momento si expander a nuevas áreas para el cultivo o si maneja las ya existentes en un contexto de aumento de los costos de transporte. Simulamos el modelo teórico a partir de datos sobre los cultivos permanentes en la selva alta del Perú. Los resultados del modelo establecen que hay un límite a la expansión de la frontera agrícola en la selva dado por los costos de transporte. Este límite puede ser superado en un contexto de libre disposición de mano de obra cada vez que estos costos disminuyen y/o aumentan el precio pagado para el cultivo de la tierra. 
Por último, las principales recomendaciones de este trabajo destacan la subordinación de la política de transportes a la agroforestería y a la conservación de las políticas de los ecosistemas forestales. Políticas forestales de diseño agroforestales deben considerar el impacto diferencial de la construcción de carreteras y caminos rurales por la pérdida de la cobertura forestal, y también en la producción sostenible de alimentos, teniendo en cuenta que la deforestación no es acelerada por la mera existencia de caminos, sino por los incentivos presentados a los colonos para orientar sus esfuerzos hacia la limpieza de nuevas áreas forestales.

Palabras clave: Amazonas Peruano, agricultura, costos de transporte, deforestación.

\section{References}

Angelsen, A. 1999. Agricultural Expansion and Deforestation: Modelling the Impact of Population, Market and Property Rigths. Journal of Development Economics 58:185-218.

Angelsen, A. 2010. Policies for Reduced Deforestation and their Impact on Agricultural Production. PNAS Journal 107:19639-19644.

Angelsen, A., E. Katemansimba, and J. Aarrestad. 1999. Why do farmers expand their land into forest? Theories and evidence from Tanzania. Environment and Development Economics 4:313-331.

Barbier, E. 2001. The economics of tropical deforestation and land use: an introduction to special issue. Land Economics 77:155-171.

Barbier, E. 2004. Explaining agricultural land expansion and deforestation in developing countries. American Journal of Agricultural Economics 86: 1347-1353.

Barbier E., and J. Burges. 1997. The economics of tropical forest land use options. Land Economics 73:174-195.

Bulte, E., and D. Van Soest. 1999. A note on soil depth, failing markets and agricultural pricing. Journal of Development Economics 58:245-254.

Chomitz, K., and D. Gray. 1996. Roads, land use and deforestation: A spatial model applied to Belize. The World Bank Economic Review 10:487-512.

DeFries, R., T. Rudel, M. Uriarte, and M. Hansen. 2010. Deforestation driven by urban population growth and agricultural trade in the twenty-first century. Nature Geoscience 3:178 - 181

Deng, X., J. Huang, E. Uchida, S. Rozelle, and J. Gibson. 2011. Pressure cookers or pressure values: Do roads lead to deforestation in China? Journal of Environmental Economics and Management 61:79-94.

Escobal J., and M. Torero. 2000. ¿Cómo enfrentar una geografía adversa?: el rol de los activos públicos y privados. Documentos de Investigación dt29, Grupo de Análisis para el Desarrollo (GRADE). Available online at: http://www.grade.org.pe/ download/pubs/ddt/ddt29.pdf (Website accessed November, 2010).

Ehui, S.K., and T.W. Hertel. 1989. Deforestation and agricultural productivity in the Côte d'Ivoire'. American Journal of Agricultural Economics 71:703-711.

Hanley, N., Shogren, J., and White, B. 1997. Environmental Economics: in Theory and Practice. Oxford University Press. England.

INRENA-Instituto Nacional de Recursos Naturales. 2000. http://dgaaa.minag.gob.pe/index.php/publicaciones-y-estudios/inrena (Website accessed: January, 2012).

López, R. 1996. Recursos verdes en América Latina: mecanismos de sostenibilidad p. 353- 385. In: Braen, D. and Glave, M. (eds.). Recursos Naturales y Desarrollo Un Diálogo Canadiense Latinoamericano. Cieplan, Consorcio de Investigación Económica y Social. Lima.

López, R. and M. Niklitschek. 1991. Dual economic growth in poor tropical areas. Journal of Development Economics 36:189-211.

Klemick, H. 2011. Shifting cultivation, forest fallow, and externalities in ecosystem services: Evidence from the Eastern Amazon. Journal of Environmental Economics and Management 61:95-106.

Morton, D., R. DeFries, Y. Shimabukuro, L. Anderson, E. Arai, F. del Bon Espirito-Santo, 
R. Freitas, and J. Morisette. 2006. Proceedings of the National academy of Science of the Unite States of America 103:14637-14641.

Mueller, B. 1997. Property rights and the evolution of a frontier. Land Economics 73:42-57.

Nelson, G., V. Harris, and W. Stone. 2001. Deforestation, land use, and property rights: Empirical evidence from Darién, Panama. Land Economics 77:187-205.

Pascual, U., and E. Barbier. 2001. A Model of Optimal Labour and Soil Use with Shifting Cultivation. Fondazione Eni Enrico Mattei (FEEM). Milán, Italy. Nota Di Lavoro Series 83.

Piu, C.H. and M. Menton. 2013. Contexto de REDD+ en Perú. Motores, actores e instituciones. Documentos Ocasionales 90. Bogor, Indonesia: CIFOR. PNUMA-Programa de las Naciones Unidas para el Medio Ambiente. 2002. Caribbean environmental law development and application: Environmental legislative and judicial developments in the
English-speaking Caribbean Countries in the contex of compliance with Agenda 21 and the Rio Agreements. México D.F., Oficina Regional para América Latina y el Caribe. May.

Reis, E., and D. Weinhold. 2004. Land use and transportation costs in the Brazilian Amazon. University of Wisconsin - Madison, Department of Agricultural and Applied Economics. Staff Paper Series No. 467. 32 pp.

UNODC. 2006. Monitoreo de Cultivos de Coca en el Perú 2005. Report June 2006, United Nations Office of Drugs and Crime (UNODC).

Wachholtz, R. 1996. Economía de los sistemas agrícolas en el valle Apurímac, Perú. Report for the Project Services Office of the Unites Nations, Lima Peru.

Weinhold, D., and E. Reis. 2008. Transportation costs and the spatial distribution of land use in the Brazilian Amazon. Global Environmental Change 18:54-68. 
